УДК 35.088.6(477)

https://doi.org/10.52058/2708-7530-2021-9(15)-111-119

Кашлакова Ася Ігорівна аспірантка, Навчально-науковий інститут публічного управління та державної служби Київського національного університету імені Тараса Шевченка, завідувач сектору «Навчально методичний центр» Управління персоналу Державної міграційної служби України, вул. Володимирська, 9, м. Київ, 01001, тел.: (099) 074-08-62, e-mail: kashlakova@gmail.com, https://orcid.org/0000-0002-3995-2506

\title{
ДЕФІНІЦІЯ «ТАЛАНТУ» В СИСТЕМІ УПРАВЛІННЯ ТАЛАНТАМИ. ДІАЛЕКТИЧНИЙ АНАЛІЗ
}

Анотація. Глобальний світовий ландшафт працевлаштування та способу життя стрімко змінюється, а заразом змінює і структуру попиту на нові індивідуальні та колективні компетентності працівників. В новому світі вже не актуальні підходи до управління людьми, які були розроблені для минулої епохи. Доба тотальної автоматизації та збільшення мобільності поступово стирає межі між фрілансерами, аутсорсерами і аутстаффером, глобалізація стимулює вільне переміщення робочої сили і капіталу в місця з більш сприятливими умовами та визначає нові способи взаємодії, а «війна за таланти» набуває міжнаціонального масштабу.

Держава цифровізує власні процеси, в тому числі, надання адміністративних послуг з використанням інформаційних технологій, разом 3 цим у суспільстві збільшується попит на безпеку та персоналізовану підтримку громадян з боку державних інституцій. У зв'язку із чим більше половини державних службовців потребують значного донавчання та перенавчання, особливо у сфері технічних навичок та людино орієнтованих послуг.

Постає нагальна потреба у з'ясуванні сутність феномену «талант» на державній службі в Україні в науковому дискурсі. Акцентується увага на тому, що під час дослідження поняття «талант» доцільно звертатись не лише до суб'єктивного чинника, але й розглядати його в індивідуально - особистісному прояві та в цілісно-узагальненому для формулювання єдиного підходу до управління талантами на державній службі в Україні.

Існування на ринку праці усіх чотирьох поколінь працівників одночасно ставить перед службами управління персоналом бізнес структур та державних органів нові задачі серед яких: застосування нових інструментів ідентифікації талановитих працівників, розробка нових моделей оптимізації витрат в умовах тотальних змін; масштабування використання цифрових інструментів; використання стратегічного планування для підготовки до майбутнього та подолання нестачі талановитих працівників, які оперативно та ефективно 
вирішуватимуть конкретні задачі. У зв'язку із чим, викладено аргументи на користь вироблення єдиних підходів до тлумачення поняття «таланти» в органах державної влади в науковому дискурсі та закріплення їх в нормативно-правових актах України.

Ключові слова: державне управління, талант, управління талантами, система управління талантами, державна служба, HR-менеджмент.

Kashlakova Asia Ihorevna Postgraduate student, Educational and Scientific Institute of Public Administration and Civil Service of the Taras Shevchenko National University of Kyiv, Head of Sector "Education and Methodical Center" of Human Resources Department, State Migration Service of Ukraine, Vladimirskaya St., 9, Kiev, 03057, tel: (099) 074-08-62, e-mail: kashlakova@gmail.com, https://orcid.org/00000002-3995-2506.

\section{DEFINITION OF "TALENT" IN THE TALENT MANAGEMENT SYSTEM. DIALECTIC ANALYSIS}

Abstract. The global world landscape of employment and lifestyle is changing rapidly, and at the same time changes the structure of demand for new individual and collective competencies of workers. In the new world, the approaches to people management that were developed for the past are no longer relevant. The era of total automation and increased mobility is gradually blurring the boundaries between freelancers, outsourcers and outstaffers, globalization stimulates the free movement of labor and capital to more favorable conditions and leads to new ways of interaction, and the "war for talent" is gaining momentum.

The state automates its own processes, including the provision of administrative services using information technology, while society increases the demand for security and personalized support of citizens by state institutions. As a result, more than half of civil servants require significant additional training and retraining, especially in the area of technical skills and people-oriented services.

There is an urgent need to clarify the essence of the phenomenon of "talent" in the civil service in Ukraine in scientific discourse. Emphasis is placed on the fact that when studying the concept of "talent" it is advisable not only to address the subjective factor, but also to consider it individually - personally and in a holistic way to formulate a unified approach to talent management in the civil service in Ukraine.

The existence of all four generations of workers in the labor market simultaneously poses new challenges to personnel management services of business structures and government agencies, including: the use of new tools to identify talented workers, the development of new models of cost optimization in total change; scaling the use of digital tools; use of strategic planning to prepare for the future and overcome the shortage of talented employees who will quickly and effectively solve specific tasks. In this regard, the arguments in favor of developing common approaches to the 
interpretation of the concept of "talents" in public authorities in the scientific discourse and their consolidation in the regulations of Ukraine.

Keywords: public administration, talent, talent management, talent management system, state service, HR-management.

Постановка проблеми. Сьогодні світ вступив в еру «Індустрії 4.0», основною тенденцією якої є об'єднання фізичного та цифрового світу. Четверта промислова революція передбачає новий підхід до виробництва, який заснований на впровадженні інформаційних технологій в промисловість, масштабної автоматизації бізнес процесів та запровадженні штучного інтелекту, що фундаментально змінить життя людей, і як наслідок, підходи до організації праці.

В найближчому майбутньому світ чекатимуть зміни такого масштабу та такої складності, з якими світова спільнота ще ніколи за часи свого існування не стикалась.

Відповідно до дослідження компанії Ernst\&Young LLC «Megatrends 2020 and beyond», основними глобальними тенденціями під впливом яких відбуваються зміни у світі вже сьогодні є технології, демографія, глобалізація та екологія (в тому числі і пандемія COVID-19) [1].

3 огляду на зазначений контекст, увесь корпоративний світ увійшов в цифрову реальність $з$ новими поведінковими моделями. У результаті швидкість та якість прийняття рішень стала актуальною «управлінською валютою», тому потреба в оптимізації бюджету та збереженні талантів стає дедалі актуальнішою. Пандемія ще більше «підсвітила» проблему розвитку i накопичення унікальних знань та компетентностей для організацій, а тим більше для державних органів.

Як результат, роботодавцям стає дедалі складніше залучати й утримувати талановитих співробітників. Умови праці на державній службі не витримують конкуренції з комерційним сектором. Більшість існуючих моделей швидко застарівають, оскільки не відповідають викликам новітніх технологій, мінливим потребам суспільства і зростаючим можливостям кандидатів.

Аналіз останніх досліджень і публікацій. У вітчизняній та зарубіжній науковій літературі питання вироблення єдиного підходу до розуміння поняття «талант» у світлі управління талантами $є$ достатньо популярною. Серед наукових праць можна виділити: П. Друкер, Ч. Лендрі, М. Майклаз, Р. Флорида, Д. Уоткінс, Д. Шеперд та ін.

Разом 3 тим, різні аспекти управління людськими ресурсами на державній службі в Україні загалом та закладення базових основ формування системи управління талантами в Україні висвітлюється в наукових розробках таких вітчизняних науковців, як: О. Васильєва, Н. Гончарук, Г. Захарчин, С. Зелінський, О. Линдюк, Н. Обушна, Л. Прудиус, О. Петроє, С. Селіванов та ін. 
Метою статті є систематизувати основні теоретичні підходи до визначення терміну «талант». У статті актуалізовано доцільність формування правового підгрунтя у розуміння терміну «талант» на державній службі в Україні.

Виклад основного матеріалу. Сучасність змінює наші уявлення про талановитих працівників. На сьогоднішній день організації не боряться 3 талантами, вони реалізують концепції вирощування своїх талановитих працівників. Раніше в HR-сфері існувало таке поняття як «теорія бульбашки», де талановитий працівник пробивався «в люди» самостійно. Тепер «теорію бульбашки» змінює парадигма «управління талантами». У зв'язку із змінами, які відбуваються у світі, змінюються і вимоги до компетентності талановитих працівників. В управлінській теорії прийнято визначати рівень талановитості співробітника, в залежності від обсягу оволодіння ним «м'якими» та «жорсткими» навичками. Талановиті співробітники, безумовно, повинні мати високий потенціал, вміти легко орієнтуватись в оперативних процесах та відмінно знати технологію роботи. Проте, на сьогодні, така категоризація лише обмежує можливості організації в розвитку талановитих працівників. Все більше дослідників пропонують використовувати чотирьохмірну модель компетентностей працівників, до якої включені:

- контекстні навички (вузькоспеціалізовані) - це навички, які розвиваються та застосовуються у вузькому контексті;

- крос контекстні навички - навички, які можуть бути застосовані у більш широких сферах соціальної та особистісної діяльності;

- мета-навички ( або часто застосовують таке поняття як «модальності інтелекту» працівника) - це передусім різні режими управління об’єктами у власному розумі чи фізичному світі;

- екзисценціональні навички - навички, які знаходяться на найглибшому рівні, які можуть бути універсально застосовані на протязі всього життя у різних життєвих контекстах [2].

Звідси і виникає питання про розкриття змісту поняття «талант» через призму управління персоналом.

Працівникам організації, особливо в контексті талант-менеджменту, важливо розуміти, що їх чують та до них прислухаються. Елемент залученості $€$ надзвичайно важливим для формування лояльності працівників. Таланти визначаються як ініціативні та працелюбні, але й такі, що прагнуть розуміння і визнання. [3].

Взаємозв'язок ефективної роботи організації та розвитку персоналу завжди представляв інтерес для теоретиків та практиків менеджменту, але категорія талант особливо не розроблювалась та детально не розглядалась.

Вперше талант згадується у 1990 році консалтинговою компанією «McKinsey» у звіті «Війна за таланти», який став предметом дискусії на корпоративних зустрічах [4].

За визначенням М. Майклаза, талант - це сукупність здібностей людини, 
властивих їй обдарувань, умінь, знань, досвіду, інтелекту, розважливості, характеру і енергії, а також здатність до навчання і росту.

Окрім цього, він виділяє і окреме поняття «управлінський талант» - це «поєднання гострого стратегічного розуму, лідерських здібностей, емоційної зрілості, навичок спілкування, підприємницьких інстинктів, функціональних навичок, вміння досягати результатів, а також здатності залучати і надихати інші таланти» [4].

Доволі часто до категорії талановитих працівників зараховують тих, хто здатний демонструвати результати виконання виробничих завдань вищі за інших. [5].

Дослідники з'ясували, що менеджери лідируючих компаній розуміють цінність талановитих співробітників та враховують дану обставину в управлінні персоналом компаній.

Талановитою визначають людину, яка має якісно високий рівень прояву здібностей та обдарованості в їх поєднанні з творчою, продуктивною працею, наслідком якої є створення видатних творінь в науці, технології, економіці, мистецтві, культурі тощо [6].

Проте, станом на сьогодні, чіткого визначення управлінського таланту не існує, так само як і не існує універсального визначення видатного управлінця, тому що вимоги в різних організаціях відрізняються.

В Україні термін «талант» законодавчо не визначений. В науці та практиці поняття «таланту» тлумачать дуже широко в залежності від сфери застосування.

Так, варіативність визначення цього терміну суттєво обмежує формування єдиного підходу до управління талановитими співробітниками на державній службі в Україні.

Сьогодні використовують такі підходи до розуміння поняття «талант»:

1. Талант як обдарованість. Талант часто сприймають як природний дар, найвищій прояв розуму [7]. Талант постійний та унікальний, він даний від народження, а знання та навички, якими завдяки таланту володіє людина, неможливо набути без нього. Талант забезпечує не успіх в будь-якої діяльності, а тільки можливість досягнення цього успіху [8]. 3 таким талантом нічого особливого робити непотрібно: його не потрібно виявляти та розвивати, оскільки він проявиться та розвіється самостійно. Подібне значення закріплено до сих пір в буденному слововживанні в українській мові. Всього в національному корпусі української мови зафіксовано декілька тисяч входжень слова «талант».

2. Талант як певні знання та цінні навички [7], які необхідні будь-якій організації. Талант - це здібності та обдарованість, які можуть бути набуті по мірі набуття досвіду та навичок [8].

Іноді перший та другий підході поєднується: талант - сума людських здібностей, навичок, знань, досвіду, розумових здібностей, суджень, характеру та напористість, здібностей до навчання та росту [9].

3. Талант як результативність. Як правило про талант кажуть, що людина в силу притаманних їй здібностей може досягати видатних результатів [7]. 
В рамках даного підходу більш актуальним для характеристики процесу управління талановитими співробітниками є твердження, що це люди, які грають головну роль у досягненні успіху організації та займають лідерські позицій завдяки своїм здібностям та результативності [10].

Більшість організацій схильні використовувати даний підхід виходячи 3 простоти вимірювання та виявлення таланту: талант визначається вже досягнутими результатами, а не вкладом, який необхідно інвестувати в знання, вміння та здібності людини.

Згідно думки експертів компанії «МcKinsey», таланти - «найбільш яскраві та найкращі» співробітники, саме «передові» 10-20\% працівників найбільш цінні для організації. У бідь-якій організації 20\% співробітників приносить $80 \%$ результату. Ці 20\% співробітників, які належать до категорії «А», яких важливо утримувати в компанії та наділяти більшою мірою відповідальності та надавати більше самостійності. Категорія «В» включає $64 \%$ співробітників, «середньостатистичних виконавців», але їх вклад в компанію складає тільки $16 \%$. Остання категорія «С» - представлена $16 \%$ працівників, які приносять лише 4\% результату [11].

5. Часто можна зустріти визначення таланту як потенціалу. Талановитий працівник - це людина, яка має потенціал для подальшого просування в організації, а потенційні лідери «орієнтовані на майбутнє». Талант - це «стратегічний баланс між результативністю та потенціалом» [12]. Іншими словами, талановиті працівники - це люди, які регулярно демонструють свої видатні здібності, досягнення та можливості подальшого розвитку.

6. Талант - як інтегральна якість працівника. Талановитий працівник має вирішальне значення для підтримання якості та цілісності людського потенціалу компанії. Такі працівники повинні мати у себе внутрішні здібності, знання, досвід, інтелект, характер, а також мотивацію до навчання та професійного росту [13].

7. Талант як фактор розвитку. На початкових етапах ідентифікації потенційно талановитого працівника ключовою змінною є потенціал; на більш пізніх стадіях вимірюванням обдарованості - досягнення; а для повністю розвинених талантів визнання - це основа для їх засвідчення такого статусу.

8. Талант як процес «управління талантами». Спочатку термін «управління талантами» застосовували, щоб позначити зміни в сфері управління $\mathrm{HR}$, які робили «акцент на управління людським потенціалом або талантом» [13].

Як правило, термін «управління талантами» співвідносяться з «управлінням за компетентностями». Компетентності являють собою знання, навички, досвід та особистісні якості [7]. Таким чином, талановитий співробітник це сукупність високого потенціалу та продуктивності. В бізнес структурах, новітні методики включають в себе формування структури компетентностей для організацій, в яких вже мається словник компетентностей, які допомагають розробити посадові інструкції. 
Якщо ж говорити про міжнародний досвід у державному секторі, то в світі першопрохідцями в цій сфері були США і Сінгапур. В основі державної політики цих країн лежить поняття лідерства, таланту і меритократії, метою якого є відбір, «вирощування» потенційних лідерів. Широко практикується пошук талантів серед школярів, яким видаються урядові гранти в спеціальних навчальних закладах; згодом процес їх роботи на державній службі оцінюється діяльність по системі оцінки потенціалу, разом з тим їх матеріально мотивують, що є дуже важливим аспектом для будь-якого працівника.

На жаль, що стосується політики управління талантами на державній службі в Україні, то необхідно зазначити, що чинним законодавством не встановлено правової основи для управління талантами державних службовців.

Крім того, із Форми посадової інструкції державного службовця категорії «Б» та «В», затвердженої Порядком розроблення посадових інструкцій державних службовців категорій «Б» та «В», затвердженого наказом Національного агентства України з питань державної служби від 11 вересня 2019 року № 172-19, зареєстрованого в Міністерстві юстиції України 30 вересня 2019 року за № 1077/34048 (далі - Порядок), виключено вимоги до компетентностей державних службовцем, але попередня редакція нормативно-правового акту це передбачала [14]. Така ситуація значно гальмує швидкість ідентифікації талантів, обмежує можливості вчасного створення ексклюзивної траєкторії підтримки такого співробітника, і вкінці кінців призводить до втрати «талановитого» державного службовця.

Висновки. Зазначена ситуація відображає, що відсутність єдиного підходу до поняття «талант» на державній службі ускладнює і процес формування та розвитку системи управління талановитими співробітниками на державній службі. Адже, запорукою успіху діяльності будь-якого державного органі $\epsilon$ талановиті співробітники, а ефективне функціонування залежить від рівня розвитку його потенціалу - працівників. Талановиті державні службовці $\epsilon$ важливим активом для успішної діяльності держави, але також є унікальним ресурсом, який складно формувати та утримати, необхідно постійно зацікавлювати, мотивувати та забезпечувати розвиток.

Необхідно зазначити, що усі описані підходи до визначення таланту існують у сфері управління людським капіталом, тобто там де, талант у першу чергу сприймається як актив, який необхідно поставити в необхідний час на необхідну позицію. Така тенденція корелюється з сучасним підходом в HR менеджменті «людина до людини», що передбачає, що будь - який працівник - талант, та саме розвиток особистісної та командної ефективності у виконанні певних задач, метою яких є збільшення ефективності та результативності усієї організації, i називаються у корпоративному середовищі - талантами [8].

Це знімає 3 терміну «талант» обмеження, які накладаються на нього «теоретичними/філологічними» підходами, оскільки талант вже притаманний не лише $з$ народження, але і дорослому, а розвиток таланту відбувається усе життя i 
веде не до розтрати потенціалу, а до втілення кращих якостей у соціально значущій діяльності.

\section{Лimepamypa:}

1. Міжнародне дослідження Ernst\&Young LLC «Megatrends 2020 and beyond». URL : https://assets.ey.com/content/dam/ey-sites/ey-com/en_gl/topics/megatrends/ey-megatrends-2020.pdf (дата звернення: 23.08.2021).

2. Міжнародне дослідження Global education futures «Future Skills» URL https://www.globaledufutures.org/images/people/WSdoklad_12_okt_eng-ilovepdf-compressed.pdf (дата звернення: 23.08.2021).

3. Винничук Р.О. Формування успішного талант-бренду організації в умовах інноваційних процесів в Україні//Управління інноваційним процесом в Україні: проблеми комерціалізації науково-технічних розробок : тези доповідей VII Міжнародної науковопрактичної конференції, 17-19 травня 2018 року, Львів. - Львів : Видавництво Львівської політехніки, 2018. - С. 24-26.

4. Майклз Э., Хэндфилд-Джонс Х., Экселрод Э. Война за таланты. Пер. с англ. 5-е изд. М.: Манн, Иванов и Фербер; 2017. 280 с.

5. Ліпенцев А.В., Касприк В.Р. Управління талантами в органах публічної влади. Науковий вісник. Демократичне врядування. 2019. № 2 (24). С. 6-12.

6. Рибалка В. В. Словник із психології та педагогіки обдарованості і таланту особистості : Термінологічний словник . Житомир : Видавництво Житомирського національного університету імені Івана Франка, 2016. 423 с.

7. Гарднер Г. Структура разума: теория множественного интеллекта. Пер. С англ. М.: «Вильямс», 2007. - 512 с.

8. Теплов Б. М. Способности и одарённость // Психология индивидуальных различий. Тексты. М.: изд-во Моск. Ун-та, 1982, с. 136.

9. Boudereau J. W., Ramstad P.M. Talantship and the New Paradigm for Human Resource Management: From Professional Practices to Strategic Talent Decision Science // Human Resource Planning. 2005. Vol. 28 No 2. - P. 17 -26.

10. Hilton D. Hiring and Retaining Top Talent / D. Hilton // Credit Union Executive Journal. 2013. Vol. 40, No. 5. P. $12-16$.

11. Работа с НіРо: где их искать, и зачем они нужны [Електронний ресурс] / А. Велесюк // Карьера. HR-менеджмент. - 2015. - Режим доступу: https://www.e-xecutive.ru/career/hrmanagement/1980119-rabota-s-hipo-gde-ih-iskat-i-zachem-oni-nuzhny

12. Каппели П. Новый подход в управлении талантами в условиях неопределенности. Ведомости. 21.04.2008 № 50. URL : https://www.vedomosti.ru/2008/04/21/50\#ixzz15bz8OQi2 (дата звернення: 11.05.2021).

13. У.А. Кадырбекова. Элементы талант-менеджмента в подготовке кадров в Республике Казахстан// Проблемы современной экономики: Сборник материалов XXIV Международной научно-практической конференции Под общей редакцией доктора экономических наук Ж.А. Мингалевой, кандидата экономических наук С.С. Чернова, 15 апреля 2015 г. Новосибирск, С. $154-158$.

14. Про затвердження Порядку розроблення посадових інструкцій державних службовців категорій “Б” та “В”: Наказ Національного агенства України з питань державної служби № 17219 від 11.09.2019. URL : https://zakon.rada.gov.ua/laws/show/z1077-19\#Text (дата звернення: 11.08.2021). 


\section{References:}

1. Megatrends 2020 and beyond. (2020). Ernst\&Young LLC. Retrieved from https://assets.ey.com/content/dam/ey-sites/ey-com/en_gl/topics/megatrends/ey-megatrends-2020.pdf [in English].

2. Global education futures «Future Skills». (n.d.). Retrieved from https://www.globaledufutures.org/images/people/WSdoklad_12_okt_eng-ilovepdf-compressed.pdf [in English].

3. Vynnychuk, R.O. (2018). Formuvannia uspishnoho talant-brendu orhanizatsii v umovakh innovatsiinykh protsesiv v Ukraini [Formation of a successful talent brand of the organization in the conditions of innovation processes in Ukraine]. Upravlinnia innovatsiinym protsesom $v$ Ukraini Management of innovation process in Ukraine: problems of commercialization of scientific and technical developments : Proceedings of the VII International scientific-practical conference. (pp. 24-26). Lviv: Vydavnytstvo Lvivskoi politekhniky [in Ukrainian].

4. Michaels, E., Handfield-Jones, H., Axelrod, B. (2017). Voina za talanty [The War for Talent Hardcover]. (5th ed.). Moscow: Mann, Ivanov i Ferber [in Russian].

5. Lipentsev, A.V., Kaspryk, V.R. (2019). Upravlinnia talantamy v orhanakh publichnoi vlady [Talent management in public authorities]. Naukovyi visnyk. Demokratychne vriaduvannia - Scientific Bulletin. Democratic governance, 2(24), 6-12 [in Ukrainian].

6. Rybalka, V.V. (2016). Slovnyk iz psykholohii ta pedahohiky obdarovanosti i talantu osobystosti [Dictionary of psychology and pedagogy of giftedness and talent of the individual]. Zhytomyr: Vydavnytstvo Zhytomyrskoho natsionalnoho universytetu imeni Ivana Franka [in Ukrainian].

7. Gardner, H.E. (2007). Struktura razuma: teoriia mnozhestvennogo intellekta [Frames of Mind: The Theory of Multiple Intelligences]. Moscow: «Viliams» [in Russian].

8. Teplov, B.M. (1982). Sposobnosti i odarennost [Aptitude and Giftedness]. Psikhologiia individualnykh razlichii - Psychology of individual differences. Moscow: izd-vo Mosk. Un-ta [in Russian].

9. Boudereau, J.W., Ramstad, P.M. (2005). Talantship and the New Paradigm for Human Resource Management: From Professional Practices to Strategic Talent Decision Science. Human Resource Planning, 28(2), 17-26 [in English].

10. Hilton, D. (2013). Hiring and Retaining Top Talent. Credit Union Executive Journal, 40(5), 12-16 [in English].

11. Velesiuk, A. (2015). Rabota s HiPo: gde ikh iskat, i zachem oni nuzhny [Working with HiPo: where to find them, and why they are needed]. www.e-xecutive.ru. Retrieved from https://www.e-xecutive.ru/career/hr-management/1980119-rabota-s-hipo-gde-ih-iskat-i-zachem-oninuzhny [in Russian].

12. Kappeli, P. (2008). Novyi podkhod v upravlenii talantami v usloviiakh neopredelennosti [A new approach to talent management in conditions of uncertainty]. Vedomosti, 50. Retrieved from https://www.vedomosti.ru/2008/04/21/50\#ixzz15bz8OQi2 [in Russian].

13. Kadyrbekova, U.A. (2015). Elementy talant-menedzhmenta v podgotovke kadrov v Respublike Kazakhstan [Elements of talent management in personnel training in the Republic of Kazakhstan]. Zh.A. Mingaleva, S.S. Chernov (Eds.). Problemy sovremennoi ekonomiki - Problems of modern economy : Proceedings of the XXIV International scientific and practical conference. (pp. 154-158). Novosibirsk [in Russian].

14. Nakaz Natsionalnoho ahenstva Ukrainy z pytan derzhavnoi sluzhby "Pro zatverdzhennia Poriadku rozroblennia posadovykh instruktsii derzhavnykh sluzhbovtsiv katehorii " $\mathrm{B}$ " ta "V" : vid 11.09.2019, № 172-19 [Order of the National Agency of Ukraine for Civil Service Affairs "On approval of the Procedure for development of job descriptions for civil servants of categories " $\mathrm{B}$ " and "V": from September 11, 2019, № 172-19]. zakon.rada.gov.ua. Retrieved from https://zakon.rada.gov.ua/laws/show/z1077-19\#Text [in Ukrainian]. 